\title{
Romanian Woman Involvement in Governance after 1990
}

\author{
Matei Elena ${ }^{A *}$, lațu CorneliuB ${ }^{\mathrm{B}}$, VertConstantin ${ }^{\mathrm{C}}$ \\ Received: November 2009| Revised: February 2010 | Accepted: February 2010
}

\begin{abstract}
This study highlights forms of gender inequality in post-communist Romania, generated by an unsustainable political algorithm which marginalizes women and fails to use their potential, both in politics and in formal and informal resistance, and maintains women's traditional duties as a type of environmental injustice.

Having as a starting point the assertion that equality, as required by a democratic and developed country, plays a key role in society issues, the study analyses, using human geography pathway, a series of demographic data on Romanian women and attempts to explain the observed fluctuations, both at a national and regional level and correlates them with women's degree of representation in politics, governance. It aims and focuses at analyzing gender inequality through the women's participating in governance after 1990 and their overall effects and feedbacks on the society.
\end{abstract}

The results show the paradox between the prevalence of female population both in number and as workforce and its unequal involvement in all governs of Romania's post-communist period and as a new EU member.

The study also draws several priorities of women politics, to alleviate this type of injustice, which could help the future society development.

Keywords: gender inequality, woman rights, employment, governance

\section{Introduction}

Although women represent half of the world population, in many countries women's role is still related to childbearing, childcare and household duties instead of successful careers (Jaggar, 2002). Throughout history, women have slowly but steadily become involved in farming, industries or services, as a result of economic development and /or after the implementation of gender equality policies. For the vast majority of them, however, this implies new tasks, as the employee status is coupled with household chores while gender equality and women's rights policies remain in many countries only at a theoretical level.

Although in Romania, as in other countries of the world, the female population outnumbers the male, women have entered in politics, administration and economy only in the past 50 years.

The first attempts to reposition women in society date back to 1923 , when the feminist movement became involved in formulating the Constitution of 1923 (Botez, I990). These efforts were materialised only in the Constitution of I938 which granted women the right to vote. Before and even after I938, women's role was linked primarily to family duties and certain social and cultural activities. After 1948, the communist regime saw the ratification of the Women's Rights Convention in 1952 as a golden opportunity to convince the society of its desire to embrace equalitarianism. After the fall of communism, the Romanian Constitution of I99I, then Law 202/2002 guaranteed human rights in a

\footnotetext{
A Human Department, Faculty of Geography, University of Bucharest, Bucharest, N. Balcescu Avenue, no.1, 11041, e-mail: matei@geo.unibuc.ro

B Geography Department, Al. I. Cuza University, Iasi, Carol I Avenue, no.11, 700506, e-mail: ciatu@uaic.ro

c Geography Department, West Timisoara University, Timisoara, V. Parvan Street, no. 4, e-mail: cvert_uvt@yahoo.com

*Corresponding author: Elena Matei, e-mail: matei@geo.unibuc.ro
} 
new European and world context, having as a priority ensuring equal opportunities for all.

Despite the clarity of the legal framework, Romania is still confronted with an inherent contradiction as far as women's rights are concerned: on one hand, there is the positive legacy of communism - a policy of equal opportunities for women, maintained under the current legislation - and on the other hand, there is the traditional mindset according to which women's main duties are giving birth, rearing and educating their children. In fact, women are granted equal opportunities only in theory, while in practice, the situation is different. For instance, women's participation in politics is restricted as a result of unfair practices thought which the positions on local and national electoral lists are filled, using criteria such as financial status, affiliation to certain political factions, and the expected benefits for certain interest groups (Rutherford, 20oI; Claringbould and Knoppers, 2007). In most cases, while men dominate senior management positions, women are promoted on lower managerial positions mainly through their extensive social networks (based on kinship, friendship or political affiliation etc.).

Outside this political system, the vast majority of the population who does not belong to the network of political influences has identified other opportunities for personal and professional fulfilment such as the business sector.

\section{Problem Formulation}

In the last years gender equality is a topic for mass media and academic research: sociology, journalism, economy and medicine as well. Using human geography pathway we tried to seek an integrative answer, combining spatiality with temporality, quantitative analyze of female population characteristics and their representation in governance with qualitative research upon the perception of women about their role as a driven force for solving gender inequalities as environmental justice.

The main question of the study is: if more than half of population is female and Romania applied gender equity since I938, why the woman position in governance and other institution remained unimportant in number and power?

In this context, the study aims at analyzing gender inequality through the women's participating in governance after 1990 and their overall effects and feed-backs on the desired modern society (Chelcea, 2007). The guiding idea for this article, as voiced by Ortansa Satmari (supporter of the feminist movement in the ' 30 and militant for women's right to vote and to be elected) in 1938 , is: 'Without women's collaboration with men, each with their specific qualities, neither superior nor inferior ones to the others, but only different, it is impossible to have a normal and harmonious evolution on the ascending scale of progress' (Jurnalul National, 2007).

\section{Methods and methodology}

The study starts from the empirical following questions:

- What are the demographic characteristics of the female population itself and as labour force in Romania?

- To what extent are women represented in Romanian governance?

- Which and why are political inequality forms of women at the down of this new millennium in this country?

This article pursues, therefore, the research stream that focuses on women's involvement in governance as an expression of gender equality appliance and as a main starting point for legal elimination of other discrimination forms.

The paper is structured in two parts: one is focused on female demography and the second, on the woman's representation in governance. For the first approach it were chosen several simple indicators using secondary external data (NIS, Govern) like genders structure, ratio female-male, workforce structure, while in the second part it combines indicators concerning the women presence in Governmental bodies, at national or local levels, with the results obtained from 20 semistructured interviews, taken in 2008, summer, in urban areas, different as the population's size: $\mathrm{Bu}-$ charest, Predeal, Botosani and three in rural areas: Suceava, Mehedinti and Sibiu counties.

Due to the huge amount of data, the study has took information using Censuses between I9I2 and 2002 to reveal the dynamics of female population; for gender ratio, employment - cross period I990-2005 and 2005 as a reference year with the highest value of femininity rate; while the women's participation in governance, refers to whole period: $1990-2009$.

\section{Romanian Women: Facts and Figures}

\section{Numbers, gender structure and spatial patterns}

Romania's census data shows a continuous increase in population from I9I2 to I992, with a peak in 1990 , when there were registered more than 23.2 million inhabitants, as a result of over 30 years of communist policy encouraging births. The number of females follows the same trend, with a maximum in I990 (II, 75 million) (National Institute of Statistics, 2007). In fact, the dynam- 
ic of crude numbers demonstrates that the population, both the number of women and the total, almost doubled between I9I2 and I992. However, the female to male ratio presents fluctuations in women's number with maximum values after The Second Worlds War (51.7\%) and in 2002 (51.3\%). The fact that there are more women than men can be related to many factors such as: the life expectancy model, social and economical events, environmental problems etc. (Caselli and Vallin, 20oI).

Many studies have shown that, at birth, the number of males exceeds the number of females. Since I662, J. Graunt, in his studies on the UK population, had asserted that, at birth, males outnumber females: a ratio of I04-I06 boys to Ioo girls. Out of the total number of children born alive, the percentage of males is $51 \%$, and the percentage of females is $49 \%$ (Cavalli-Sforza and Bodmer I97I; Pressat I983; Henry and Blum, I988; Chahnazarian, I988; Tremblay, I997; Sieff 1990; Caselli and Vallin, 200r; Noin 2005).

The Romanian male to female ratio at birth fluctuates around 106\%, but the spatial distribution presents strong variations, from a maximum of over $122 \%$, in remote areas, to a minimum of $90 \%$ in developed ones. This pattern confirms the theory that the value of the ratio differs from one region to another, being higher in rural areas and developing countries than in urban areas and developed countries (Noin, 2005).

The female to male ratio is influenced not only by biological variables at birth or during conception period but also by a multitude of factors that affect a person's lifespan (Weinberg et al., I995; Harlap, 1979; Greenberg and White, 1967; Whitfield, Bayliss and Clarke I987; James I996b; Almagor, Schwed and Yaff 1998, Brian and Jaisson, 2007). Males and females are exposed to different risks either medical - such as predispositions to diseases, complications at birth - or social such as wars, dangerous work environments, resulting in differences between female and male mortality rates which are reflected in the female to male ratio for each age group. Under these circumstances, males are predominant in the under 20 age group, for the 20 to 40 age group there are roughly equal numbers of men and women and for the over 6os group women are predominant (Noin, 2005).

In Romania, between 1990 and 2005, as a cross period reference, the female to male ratio has increased constantly from I02.7 \%, in I990 to I04.9\% in 2005 (fig. I.). The three main age groups do not follow Noin's (2005) classification. Thus, males are predominant in the $0-34$ age group, the balance $( \pm \mathrm{I} \%)$ is specific to the $35-44$ age group and females are predominant for the over 45 age group (fig. 2.). The values might be influenced by men's migration to work in Western Europe, but in the absence of relevant data, it is impossible to establish a coherent explanation. On the other hand, it is generally acknowledged that after the age of 70 , the male to female ratio is $\mathrm{r} / 2$, but in Romania this value is not reflected in any of the elderly groups, as the ratio for group $70-84$ is $\mathrm{I} / \mathrm{I} .3$ and after 85 years is $\mathrm{I} / \mathrm{I} .5$. This may indicate an improvement in men's lifestyles: self-care, healthy diet, giving up smoking etc. (Groza and Muntele, 2005; Dumitrache, 2004).

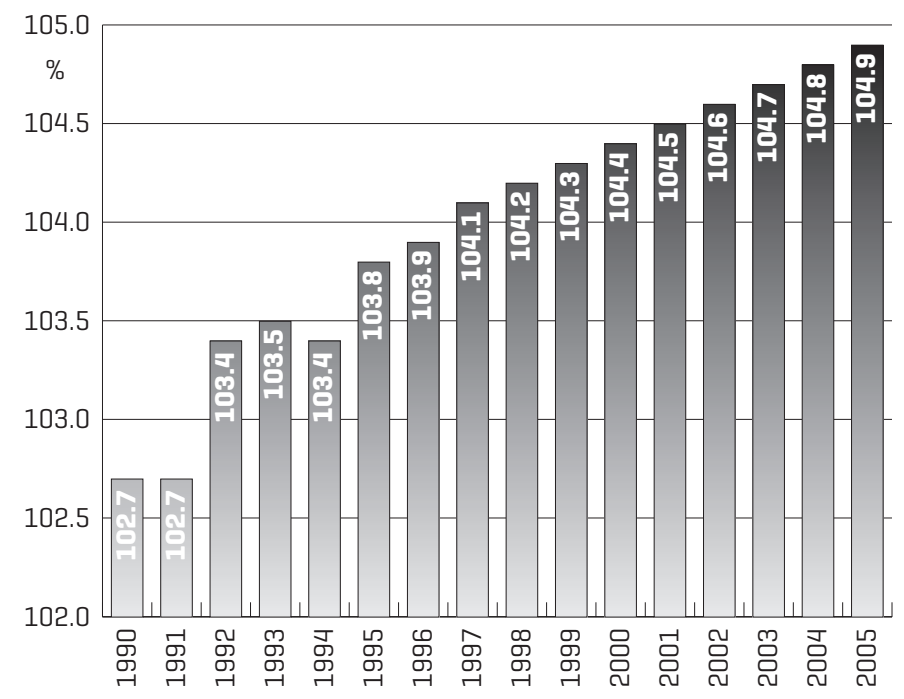

Figure 1. The average femininity ratio in Romania between 1990 and 2005

Processed after NIS, 2007

The values are in accordance with the assertions that life expectancy rose rapidly in the twentieth century due to improvements in public health, nutrition and medicine (Rosenberg, 2007) and that the differences in life expectancy between men and women have been reduced, as women started taking on the behaviours and stresses formerly considered specific to men (Cromie, I998). In this framework, the gender structure is slightly skewered towards females. In 2002, at the last Romanian Census, there were registered II II2 233 women, and ro 642538 men (NIS, 2002), therefore a surplus of 543492 women, representing $2.5 \%$ from the total inhabitants.

The predominance of females in the elderly groups is explained by the fact that women's life expectancy is higher than men's (Riley, 200I). For this case study, the life expectancy of women in Romania rose from 73.05 years (1990) to 75.47 (2005), while the male expectancy rose from 66,59 in 1990 to 68 ,19 years in 2005 (NIS, 2007).

According to the 2002 census, the difference between the number of females and the number of males is greater in urban areas (448 286 more women than men) than in rural areas (95 206 more women) (NIS, 2002). The greatest differences are 


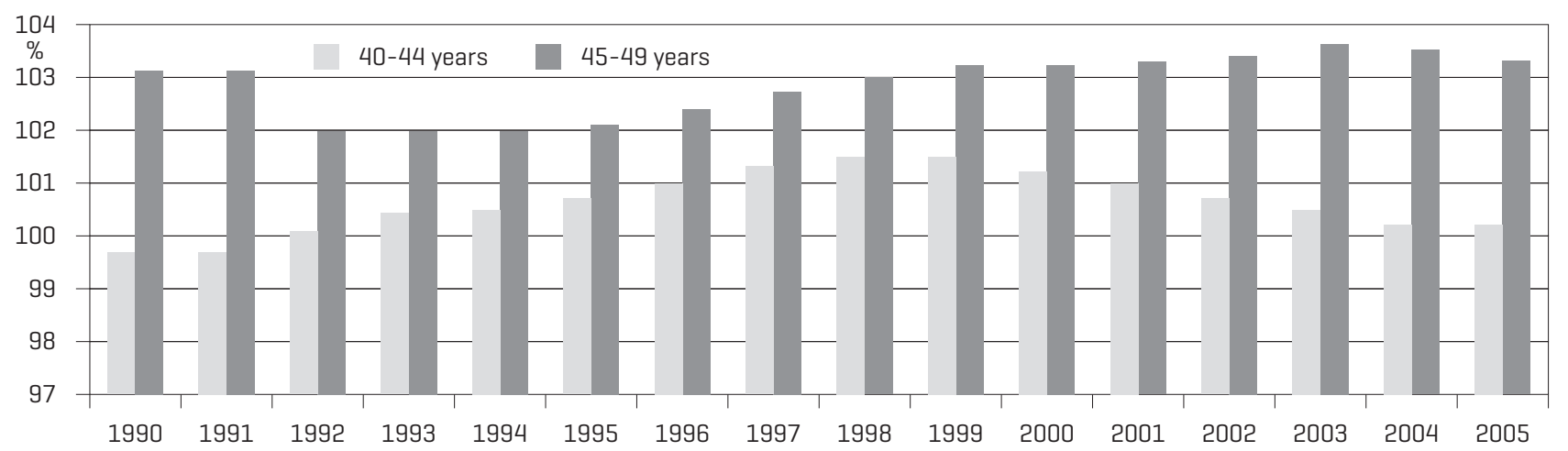

Figure 2. The femininity ratio in Romania's population for the 40-44 and 45-49 age groups, between 1990 and 2005

to be found in more developed areas such as $\mathrm{Bu}$ charest, Prahova, Timis and Galati. This situation can be attributed to rural urban migration, to economic imbalances which resulted in the feminization of the urban workforce, and to declining birth rates, which brought about a decline in the number of children and adolescents, a group characterized by higher numbers of males than of females.

When analyzing the femininity ratio for each administrative unit in 2005 , the year with the highest values for the period surveyed, it becomes apparent that all areas have a higher proportion of women (fig. 3.). However, if both the female to male ratio at birth and the overall female to male ratio are considered, we can distinguish trends that divide the country into five spatial patterns:

I. Areas with a low female ratio at birth keep a female to male ratio smaller on average than the country as whole. They have been suitable for mining, metallurgy or farming activities for several decades (Maramures, Alba and Galati counties);

2. Areas with low femininity ratio at birth and a higher female to male ratio can be divided into two types:

a) Areas with a predominantly rural population which have experienced an episode of exodus for work inside country or abroad (Olt, Neamt, Giurgiu, and Teleorman);

b) Counties either with a well developed service sector within themselves or counties bordering service-oriented areas (Dolj, llfov, Arges);

3. Regions with medium femininity birth ratio and a higher female to male ratio than that of the country average, divided into two types:

a) Counties with a rural majority and a strong tradition of farming, forestry (mountain or Moldavia Plateau);

b) Counties with a diversified economy (central and western areas);

4. Counties with a high femininity ratio at birth and a high overall female to male ratio - devel- oped and urbanized units (south and central part of the country);

5. Regions with high femininity ratio at birth and lower overall female to male ratio found in remote rural areas (Baragan Plain and The Danube Delta).

The main pools of female labour force are still located in several areas with metropolitan characteristics: Bucharest, lasi, Constanta, Cluj, Timisoara, Brasov, Craiova or along certain axes $(\mathrm{Bu}-$ charest-Ploiesti-Brasov, lasi-Roman-Piatra Neamt, Galati-Braila, Timisoara-Arad-Oradea etc) (lanoş, 2004). In fact, these concentrations of female labour force are a result of the communist politics that shifted light manufacturing (sector employing mostly women) from the countryside to urban areas (Balteanu et al., 2006), politics which also had as a side effect the erosion of the traditional family model and a subsequent decline in birth rates.

Overall, the female to male ratio varies from less than $80 \%$ in areas with the highest percentages of rural population, to less than $90 \%$ in counties either predominantly rural or depending heavily on mining and metallurgical industry, to more than 100\% in well developed and heavily populated areas and in rural areas where the elderly population represents the majority. These figures are the result of communist economic policies focused on developing heavy industry in urban areas, which caused the rural to urban migration of the male labour force (Surd, 2002), and of the more recent migration of the male labour force in search of better paid jobs in Western Europe.

\section{Romanian women and labour force employment}

In an attempt to implement a policy promoting women's rights and gender equality after I948, the communist government embarked on a strategy of full time employment for women. Despite this communist task being fulfilled, it did little to alter the traditional division of household chores between husband and wife in Romanian 


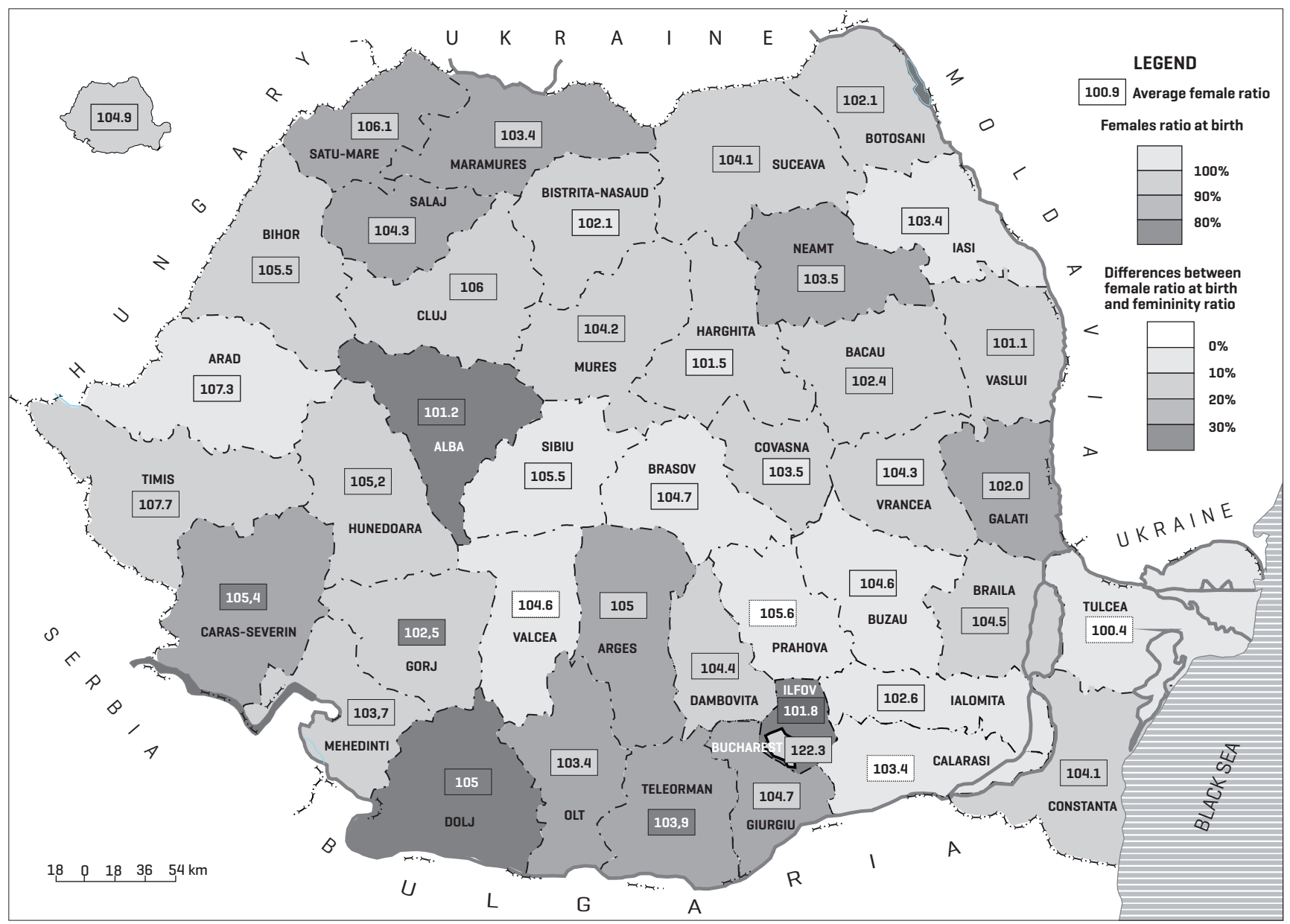

Figure 3. The femininity ratio in Romania [2005]

Source: NIS, 2007

families,women remained overburdened by responsibilities. In addition to this, women were constrained to be 'good citizens', both by bearing as many children as possible - in conformity with the famous Act (Decret) no. 770/1966 prohibiting abortion and all contraceptive methods - thus achieving the political goal of increasing the population and by acquiring many qualifications ('multilateral') in order to be suited for every required job. Otherwise, Kligman (I992) argues "the demographic and national politics turned women's body into instrument to be used in the services of state", despite the loss, of raising mother mortality by illegal abortion (Davis et al., I97I; Johnson et al., 1996). Given these circumstances, many women have a triple role: reproductive, productive and community managing works (Moser, I993), even they chose to work in heavy industry, mining etc.

However, even in the context of a closed communist economy, women have gradually shifted to jobs in light manufacturing and tertiary sector, a process continued especially after I990, when women either stayed in full time employment or started their own businesses in order to increase the families' incomes.
In order to understand women's participation in the economy, it must to analyze the following variables: the economically active female population (the female labour force, aged 18 to 58 , as a percentage of the total number of women), the employment rate and the spatial distribution of women engaged in full time employment.

The economically active female population, as a percentage of the total number of women reflects the extent of women's involvement in economy, taking into account both demographical characteristics of this subpopulation and economic features of the community. The evolution of the same indicator for males is in progression (60.5\% in 1996 and $69.5 \%$ in 2005) and in regression for women $(69.9 \%$ in 1996 and $55.3 \%, 2005)$. The trend could be associated with female workforce migration and ageing.

According to the 2002 census, Romania's total labour force represents $40.83 \%$ of the total population, but only $34.32 \%$ women are included in the labour force compared to $47.67 \%$, the figure for men. However, the employment rate is higher among women (90.62\%) compared to men (86.45\%).

The differences between the percentage of economically active women in various regions of the 
country is as high $(22.12 \%)$, indicating heterogeneity among the regions with the highest values Moldova (North East) and the West of the country - and the regions with the lowest values in Muntenia (South). Several factors were taken into account for these patterns: a well developed manufacturing or service sector, low wages and the predominance of numerous families - for Eastern regions - and women's desire to acquire a high social standard along with their Western-style mentality and traditions for Banat province (West).

As far as women's employment is concerned, there are clear differences between urban and rural areas. The percentage of economically active women is higher in urban areas (38.55\%) compared to rural areas (29.47\%), but the employment rate for rural women is higher (92.53\%) than for women living in urban areas (89.35\%). These figures can be associated with the fact that in rural, women, it is more likely, accept a poorly paid job (Murphy and Graff, 2005), are more loyal to a company and prefer a stable job, as they are often the only wage earners in the family. The forms of discrimination in the decision making process, from the family level to the national level may also play a strong role (Boserup, 2007). Between 1996 and 2006 , the employment rate registers a decrease for women and an increase for men, a trend which is reflected in the economically active population figures and partially explained by the fact that more women are less inclined to take up or stay in poorly paid employment.

The imbalances between the demand on the labour market and the available labour force in specific locations determine different patterns in women's employment in rural and urban areas (Blumenberg, 1998). In urban areas, where the proportion of economically active women is greater, a large pool of labour is available which surpasses the demand on the labour market resulting in high unemployment rates. In rural areas, although there are fewer jobs available, the labour force is less numerous and the employment rate is higher and unemployment lower. The female unemployment rate, at a national level, has oscillated in the past ro years, showing an overall increase, while the same figure for men has shown a decrease. In 2002 it reached $9.38 \%$, with $4.17 \%$ less than male unemployment rate. This peak is the result of political measures and economic restructuring resulting in the relocation or closure of large industrial plants, especially in sectors such as mining and heavy industry.

\section{Employment features}

There are two basic stages at which important career decisions are being made: the first one is the qualification stage, at which a person chooses to attend a school and the employment stage where the person enters the labour market. A series of informal factors: the availability of information, competition with men and formal: terms of employment, skills and laws can influence women's employment choices. It's obviously recognized that a woman's employment decision, including the hours worked and the type of employment and the specific job has always been influenced by her responsibilities as mother and as a contributor to the family earnings (Gilbert, I998).

Although before 1990 few people chose to take up jobs that weren't related to their formal qualifications, this situation changed after I990, as people started taking into account other factors when making their career choices, such as wages and social status.

According to the 2005 data, $\mathrm{I2} .6 \%$ of the Romanian workforce graduated a faculty, 30.7\% graduated high school, 25.5\% vocational school and I8.6\% secondary school, women represent half of the figures (NIS, 2007). The fact that in Romania, equal numbers of males and females attend school at all levels is an advantage and an important step forward for sustainable development.

However, employment statistics emphasize that in 2005 , only $0.9 \%$ of women are employers, three times less than men, I2.5\% self-employed, $21 \%$ of women are employed in family businesses twice more than males - and over $65 \%$ are employees. The process is slower than in Poland which, by the end of 1998 , registered about $37 \%$ of selfemployed women in all entrepreneurship units. (Bystydzienski, 2005). Even in this context it must be recognized "the benefit effect of the economic transformation in Eastern Europe starting with the emergence of conditions which encourage entrepreneurship mainly individually-owned business" (Bystydzienski, 2005).

When it is analyzed the proportion of women employed in various sectors of the national economy, it becomes clear that certain sectors are seen as suitable for women and thus mostly women are employed: health services, social work, education, real estate, financial services, trade and agriculture. While healthcare, education and the financial sector require specific qualifications, in real-estate, trade and agriculture the educational background is less relevant.

The highest proportion of women from the total of employees is found in the health system (excluding the auxiliary medical staff) and education. The health system had, in $2005,2 \%$ of the total labour force, out of which $80 \%$ were women: $68 \%$ of the physicians, $64 \%$ of the dentists and $82 \%$ of the pharmacists. $91 \%$ of the auxiliary medical staff was also feminine (NIS, 2007). Moreover, surveys data indicate that the number of male physicians decreased 


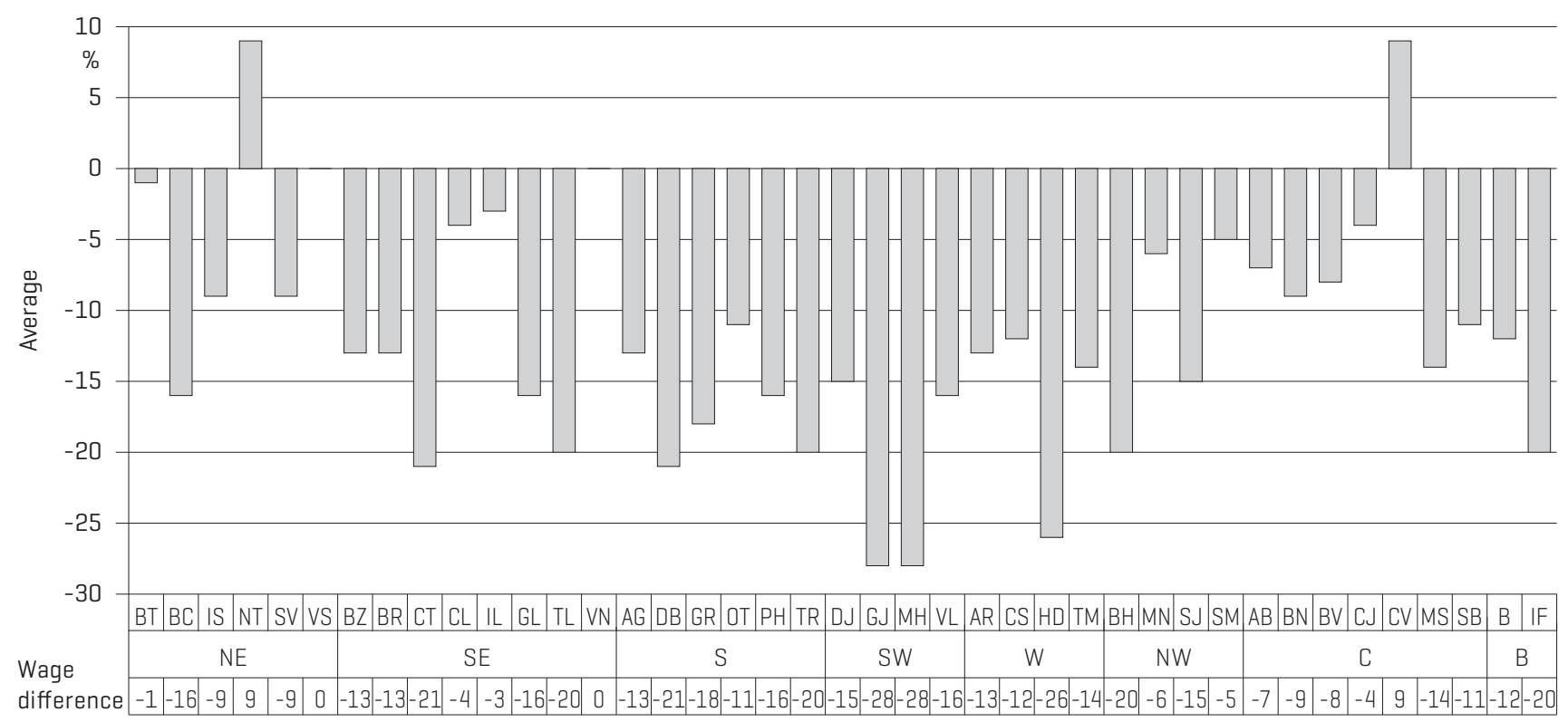

Figure 4. Wages differences between female and male, by counties, 2005

Source: NIS, 2007

in recent years and women working as nurses as well, confirming that they are attracted abroad (Raghuram, 2007; Solano and Rafferty, 2007). Thus, in Romania, there are only 2I.9 physicians for Iooo inhabitants, out of which 15 are women.

Education, having $4 \%$ of the labour force, is second sector, according to the proportion of women from the total of employees. In $2005,72 \%$ of the teaching staff was feminine, $3 \%$ more than in 1990.

Agriculture employs 31\% of Romania's labour force, out of which $52 \%$ are women. The high percentages of labour force in general and of women in particular that are employed in the agricultural sector shows that the differences in economic structure takes off Romania apart from the other European countries (Marinas, 2005).

This structure bears some resemblance both to the developing country model - with a strong involvement of women in agriculture (Falloux and Talbot, I992) - and also to the model of developed countries with largely involved of women in tertiary activities such as health-care and education.

The sectors employing mostly women belong mainly to the public domain, where salaries are generally lower compared to the private sector. This could partially explain why women's average wage is lower than men's. In 2005, Romanian women earned on average almost $12 \%$ less than men (fig. 4). Is this an evidence of discrimination against women? When analysing the wage averages for each county, it becomes apparent that while in predominantly rural areas there is little or no differences between men's and women's average wages, in more developed areas (70\% of counties) the differences are to I0-I5\%. The largest differences characterise those regions that are dependent on mining and related industries, because men's average wages are $20 \%$ higher than women's. However, there are two counties where women's average wage is higher than men's: Covasna with an equal share for both genders and Neamt, where thenumber of female workforce is higher than male.

The women's average hourly earnings as a percentage of those of men ware $82 \%$ in 2003 (Oprica, 2008) and $88 \%$ in 2005 , which reveals a continuous decreasing of unequal pay for work of equal value and also of the women's underrepresentation in high-income jobs and discrimination tendency as well.

In sum, as it is suggested by these empirical results, knowing the characteristics of female labour force would be useful in formulating and implementing public policies and very important in understanding the different responses to the factors influencing the decision to work among the different socioeconomic groups (Yamada, I985).

\section{Legislation, governance and women}

\section{Legislation on women's rights}

Romania has subscribed to all international conventions on women's rights. Romania ratified The Convention regarding women's political rights soon after it was adopted by the General Assembly of the UN (I952), granting Romanian women the right to vote and to be represented in political structures. However, while the right to vote was respected, women were hardly involved in governance within the framework of a one-party system.

Although Romania ratified in I98I the UN Convention (Law no. 342/r98I) for the elimination of all 
forms of discrimination against women, it failed to create a structure responsible with enforcing the Convention. In an attempt to reconcile the labour requirements of the rising economy with the goal of increasing the population of the country, the communist government adopted a duplicitous policy (Kligman, I992). It encouraged women to participate in the economy and to support their families financially while in the same time it has glorified maternity and promoted the traditional family model, whereby the wife is economically and psychologically dependent on the husband. In fact, the state spread the idea of its magnificent attitude to support human rights: incorporation of women in economy it would eliminate the bourgeois model of the female subordination and guaranteed job security, maternity level or childcare facilities giving special incentives for mother with more children (Kligman, I992).

Even though, in theory, women were encouraged to become involved in politics, in fact it was practically expected to stay at home, to take care of children, thus bringing a greater benefit to society (OSI, 2007).

After I990, one expects that the role of women in society, economy and politics to be repositioned in accordance with the international laws.

In Romania, the fundamental law is the Constitution which includes several articles (I6, 36, 48 ) on gender equality, human rights etc. (Romania's Constitution, I99I). The national body dealing with women's issues is The Labour, Family and Equal Opportunities Ministry. Inside the Ministry operates the National Agency for Labour Force Employment (Agentia Nationala pentru Ocuparea Fortei de Munca) created in 2005, in accordance with Law no. 202/2002, in charge of ensuring that men and women have equal opportunities in terms of employment and that the EC Order 73/2002, is respected. Another body in the same ministry, The National Agency for Family Protection, is responsible for women's issues and family policies, including organizing programs for women, proposing new laws, monitoring legislation against gender discrimination, initiating and financing women's professional training programs and addressing the problems faced by single mothers (www.anpf.ro).

Apart from governmental institutions, the civil society - either in the form of independent (ex: Romanian Women Association) or party-supported NGOs - plays a secondary role in addressing women's issues.

\section{Women in governance}

Romania, as a Republic, is organized according to the principles of separation and balance of powers: legislative, executive and judicial, within the frame- work of constitutional democracy (article I-4), (Romania's Constitution, I99I) The State's legislative power belongs to the Parliament, which comprises two chambers: Senate and Deputies (article 62) (Romania's Constitution, I99I), while the executive power belongs to the President and to Government.

Romania's Constitution stipulates and guaranties in article I6-3 that: 'The access to public, civil, or military positions or dignities may be granted, according to the law, to persons whose citizenship is Romanian and whose domicile is in Romania. The Romanian State guarantees equal opportunities for men and women to occupy such positions and dignities'.

Within this simple framework, women should not face any barriers in their attempt to become involved in politics. However, women are still poorly represented, both in central and local governments.

Between 1990 and 2008, the percentage of women in the Parliament has been low, $0.8 \%$ for Senate and Io\% for Deputies Chamber.

Immediately, after the fall of communism (I990), women's presence in Parliament was insignificant and then it gradually increased until I996, when their number was reduced again. The number has been slowly rising ever since. For the first one or two legislative periods after I990, all political parties did nothing to encourage women's participation. Nowadays, the situation is slightly improving, but men are still the vast majority in Parliament. The percentage of women in Deputies Chamber is II\% and in Senate is 7\%. Even though there are more women than men in all counties, $30 \%$ of them do not have any female representative in Deputies Chamber and 65\% do not have female representatives in Senate (fig. 5.).

Does gender equity work here? Who defends women's rights and works to address women's issues in those areas? Are there any consequences from an environmental point of view? In order to answer these questions we must look at the roots of the problem. The key-elements that influences the women's degree of participation in politics are: election system, parties' policies, women emancipation, competition inside parties for places on the electoral lists for Parliament, women's attitude toward politics and their confidence in their own capabilities and in the election system.

The voting system applied from I990 to 2008 was based on proportional representation with fixed lists, a system which, as a result of its limitations and practices of some political actors, allowed a modest presence of women in the upper structures of the state.

While left wing parties paid more attention to gender equity in politics in an attempt to include in their organisations more rural women from their 
main pool of votes - rural Moldova, the centre-left party (Democrats) recruits more emancipated and educated feminie members mainly from urban areas (Bucharest, Prahova etc.). In fact, rural women are generally drawn to left wing parties, while urban women choose centre-left, centre-right and right wing parties. Political parties will not encourage gender equity seen as a segment of environmental justice unless it serves their goal of reaching the electorate and obtaining their votes in order to have the majority of seats in Parliament.

Analysing the composition of the Romanian Government, it becomes apparent that women are occupying lower managerial positions. Usually, in the Prime Minister's Cabinet, there are no women ministers (eception 2008-2009 with three cases), I $8 \%$ of the state secretaries and almost $50 \%$ of the personal advisers are women. These figures reflect the general perception that in governance women are suited only for positions of lesser authority.

Between 1990 and 2008 there were only 7 women ministers (The Ministries of Environment, Health, Education, Environment and Justice), supported primarily by left wing and central-left parties. Only Ministry of Environment and Sustainable Development and Ministry of Justice were led in 18 years by two women (minister) for 8 years. Women have occupied leadership positions in those particular ministries, largely because the staff required here was qualified for those professions traditionally seen as suitable for women.

In most ministries, the percentage of women occupying senior positions is 20\% (2004-2008 figures). A higher proportion of women are found in the Ministry of Labour, Family and Equal Opportunities $\mathrm{M}$, which has equal numbers of men and women on senior positions, followed by the Ministry of Defence and the Economy and Finance Ministry with 60\% (males) to 40\% (females).

A special situation is found in The Ministry of Environment and Sustainable Development, an institution established after I990, which is a suitable niche for female representation. Even in this last legislative period, it gathers no women in senior positions it maintains a large participation of them at local and regional level and a specialisation according to the activity requirements. Otherwise women's vulnerability is recognized worldwide, and is attributed mainly to environmental risks at home or in the workplace (Lipson and Doiron, 2006). Through their role as family providers, consumers, producers, women are stable members of society with a key role in environment management (UN, FWCW, 1995). In Romania, as in many other countries, women play an important role in tackling environmental issues, at different levels. At home, they start children's environmental education at an early age and as housewives they can reduce the impact of their household on the environment by deciding to recycle or to reduce consumption. At the workplace, she spreads the model of sensitiveness and awareness for environment quality, being less exposed to pollutant than men. As citizens, women have the right to vote but few of them occupy high positions in political structures that would grant them an important role in decision making. However, in these circumstances many women are members or leaders of environmental NGOs, playing an active role in society, expressing their concern for nature and ecology.

The Ministry of Environment and Sustainable Development subordinates The National Environment Agency (ANPM) divided into 6 regional agencies and 42 local environment offices. Between $50 \%$ and $90 \%$ of National Environmental Agency's employees - the largest environmental institution - are women. Spatial picture of women in ANPM shows that the highest values correspond to developed regions, where men generally have a variety of job opportunities in industry or services while the lowest values are specific to less developed regions which are smaller pools of employment. Overall, qualifications required in ANPM's jobs are: biology, chemistry, physic, law, geography and environment, wide recognized s suitable for feminine professions. So, women as professionals are responsible for environmental monitoring, conservation, preservation, authorising and the implementation of environmental regulations, too.

Basically, while men, having political support, become leaders and occupy senior management positions in public institutions of authority, women are employed either on lower managerial in these institutions or in institutions that are subordinated to these. However, as these are recently founded institutions, in charge of implementing the new European regulations and dealing with the legacy of socio-economic system, their efficiency in terms of improving the quality of life/environment is not measured by men or women participating, but can be related with (Chimiak, 2003). Thus, the benefits of women' involvement in a company/ institution board was largely argued in literature (Dewatripont et al., I999; Francoeur et al., 2008; Carter et al., 2003). Artfken (2004) recognised that "diversity in gender, age, ethnicity and viewpoint can offer many benefits of a corporation including knowledge, new ideas and insights to aid problemsolving, better product positioning, enhanced strategic planning, new knowledge or opinions, and even additional accountability". For women, board membership provides an opportunity to test ideas and to support a corporation's view on public policy (Arfken et al., 2004).

Overall, women's limited participation in Government and Parliament reflects to some ex- 


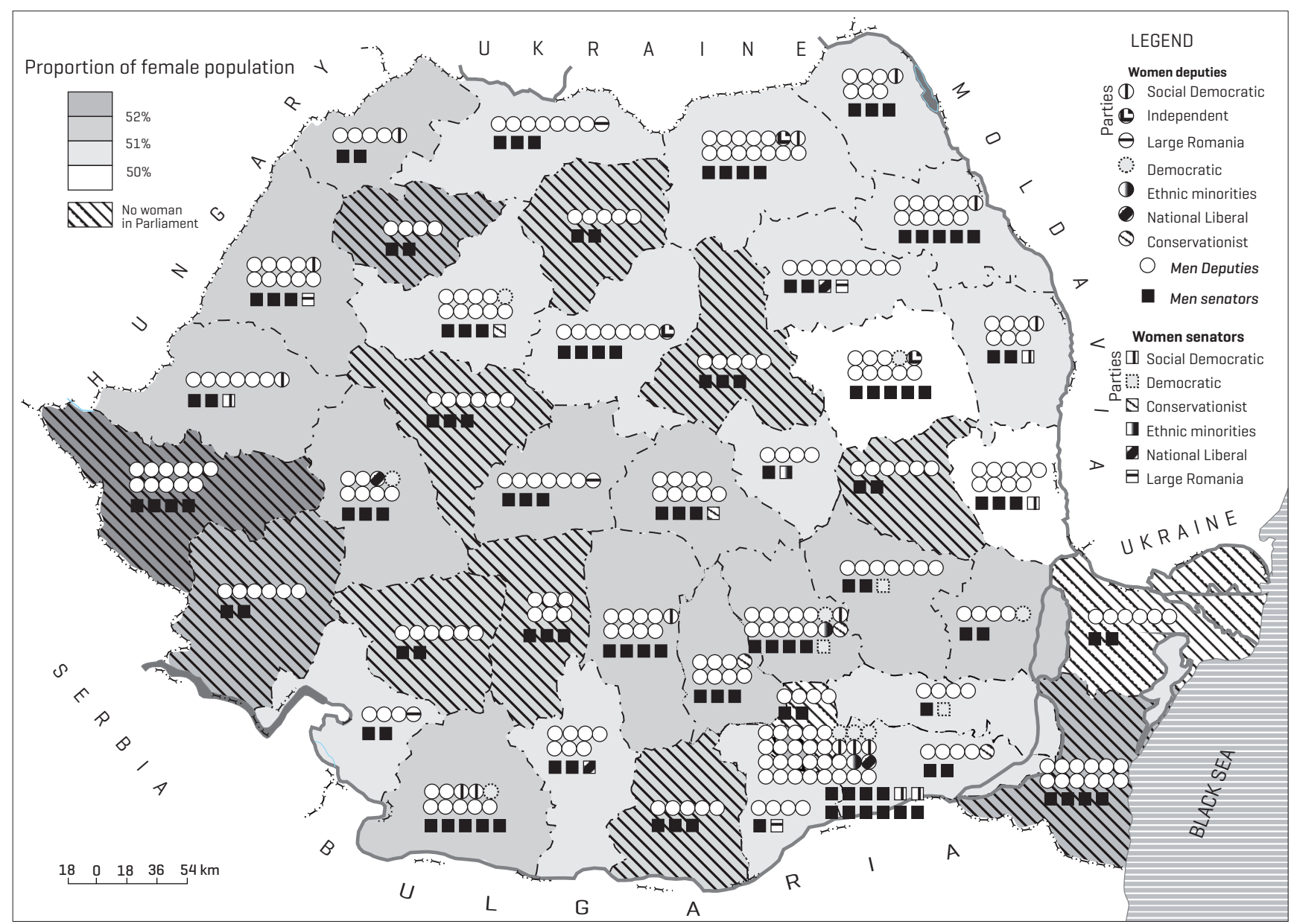

Figure 5. Women in Romanian Parliament, 2004-2008

tent the political parties' own attitude and policies concerning gender equality. The situation can also be explained by women's lack of interest in politics or as a reminiscence of the communist regime that threatened Romanian society in a suspicious atmosphere by discouraged social relationships and forced citizens to report neighbours' activities (Hord et al., I99I). Oprica (2008) states the idea that "the current patterns of gender inequality in Romania are strongly correlated with a resurgent traditionalism in society. As such, there are factors other than the communist legacy or the economic hardships of transition that negatively affect the status of women. The main such factors are the Orthodox Church and conservative political parties set against the general backdrop of traditional values and social attitudes rooted in Romanian history".

The interviews (taken in summer, 2008) reveal that most women chose careers in business and some decide not to have a career and to remain at home with the family. Overall, even though a large proportion of Romania's population still considers that women should be engaged only in household activities and raise children (rural interviewed women), there an ongoing and irreversible process of improv- ing women's participation in economy, but less visible in politics and governance, (urban interviewed women) as Hirschmann has argued too, (I993).

Thus, if it is generally acknowledged that sustainable development can only be achieved through long term policies that encourage the participation for both men and women, the Romanian political pyramid is still characterised by the absence of women at its top.

The decision making, process both in the Legislative and Government, is controlled by men who occupy the majority of senior leadership positions and therefore men can and will be held responsible for the effects of the policies they initiate, policies which represent in most cases men's mentalities and their points of view (Cornell, 1987).

Given the fact that in 2008 , a new electoral law was passed for local and parliamentary elections, based on single-winner voting, a series of changes in state structures are likely to appear as a result of the fact that voters choose a person rather than a party list, thus not allowing certain individuals, chosen by parties on less transparent criteria, to access positions of authority. This law is regarded as a panacea for the crisis of representation in Romanian politics as well as a step towards re- 
specting the principle of equality, including gender equality. The simple-plurality, single-winner voting system connects voters with elected representatives and reduces the risk of representatives being loyal only to the party (and not to their constituencies), a system which, at least in theory, allows competent women to be actively involved in decision making at a governmental level.

However, the first rounds for local elections (I June 2008) show that even under the new voting system, women are as poorly represented, exactly as before. Out of the 42 councils representatives of counties, only one of them is a woman (2.2\%) compared to o (\%) in 2004. For both reference periods, For both reference periods, the mayors of all residence municipii of counties (the I03 largest towns in Romania) are men, while out of the other municipii (a total of $99)$, only 2 of them have women-mayors (2\%); out of a total of 223 small towns, only six have women-mayors (2.6\%). In rural areas, in 2004, women were elected mayors in 106 of the 2854 communes- $3.6 \%$ while in 2008 women occupied 97 of the mayors positions. In 2008, most of the elected women are members of the Liberal-Democrat Party (PD-L), a party supported by the president which recently appeared on the Romanian political scene as it disaffiliated from the PDPNL alliance. It seems that PD-L promotes women through its policies and as part of its strategic image.

In sum, in urban areas women occupy $2 \%$ of the (political) positions of responsibility, while in rural areas the percentage dropped from $3.6 \%$ to $3.3 \%$. Many of the women elected in 2008 have occupied the same positions in past legislatures and a vast majority of them have a background in the business sector, where they excelled as managers and professionals.

Thus, after 2008, women presence in Parliament decreased: $5.8 \%$ in the Senate Chamber and to $10.4 \%$ in Deputies Chamber and almost $15 \%$ in the ministries' structure. An unexpected success is registered in the EU Parliament, because 33.3\% of Romanian representatives are women (2009).

In conclusion, before and after 2008 elections, party elites primarily acted according to seatmaximizing positions (Dawisha and Deets, 2006), using all alternatives with a rapid effect on electorate and and without to much preoccupation to gender equality. In this framework, it appears a conflict between Romania and EU concerning equal representation in decision-making etc.

\section{Conclusions}

Overall in Romania, the number of women exceeds the number of men. While males are predominant at birth and in younger age groups, there are equal numbers of males and females in mature groups, females are predominant in the over 40 age group. This structure is the result of biological and environmental variables.

Women tend to occupy positions of lesser authority than men, as a result of prejudices regarding their potential, their capacity as leaders in society and in business.

Even though on the whole, communism was a negative socio-political phenomenon, Romanian women benefited from some of its policies. The former regime initiated and put in practice policies regarding gender equality, policies that were applied for over 50 years and which encouraged women's participation in the economy. Nowadays, wmen must continue to promote their abilities on the labour market and in society and resist the informal discrimination that still occurs at the level of families or communities.

Even though women's role at the base of the Romanian Society is obvious, they still play a secondary role in governance, as long as men are predominant in Parliament and Government.

There are many examples of women with leadership abilities. Some women express their opinions and convictions on politics and environment through voting or involvment in civil society, others start businesses and lead big enterprises.

Looking into the future, it is likely that the Romanian society will maintain the traditional view according to which women should be mothers and wives first, and then professionals. However, the present international and national context supports an optimistic vision of gender equity which will be applied more often in politics and governance.

Irrespective of the configuration of the parliament for 2008-2012, one of its responsibilities, as Romania is EU member, will be promoting and respecting the "European Consensus on Development" and "The Roadmap for equality between women and men 2006-2010" which in defining of some existing areas and proposing new areas of action have selected the following six priorities: equal economic independence for women and men, reconciliation of private and professional life, equal representation in decision-making, eradication of all forms of gender-based violence, elimination of gender stereotypes and promotion of gender equality in external and development policies (European Institute for Gender Equality, 2006). The presence of equal numbers of women and men in governmental structures was a prerequisite for ensuring that the other five priorities will be respected.

\section{Acknowledgements}

We would like to thank Alexandra Petrescu (Graduate KCL-UK) for her support in reading of the English version and the anonymous referees and editor for their helpful suggestions. The paper is the result of 
several debates about woman's participation in governance with local authorities and civil society of the Romanian small towns, a sub-theme in the CNCSIS project, no. 292/2007-PNII-Ideas.

\section{References}

Arfken, D.E., Bellar, S.L., Helms, M.M. 2004. The Ultimate Glass Ceiling Revisited: The Presence of Women on Corporate Boards. Journal of Business Ethics 50, 2, I77-I86.

Almagor, M., Schwed, P., Yaffe, H. I998. Male to female ratio in newborns of grand multiparous women. Human Reproduction I3, 8, 23232324.

Balteanu, D. (eds). 2006. Romania, Space, Society, Environment. The Romanian Academy, Bucharest, 194-224.

Blumenberg, E. I998. Gender Equity Planning: Inserting Women into Local Economic Development. Journal of Planning Literature I3, 2, I3I-I46.

Boserup, E. 2007. Women's role in economic development. James \& James (Science Publishers) Ltd. United Kingdom.

Botez, C.C. I990. Drepturile femeii în Constituţia viitoare. Constituţia din 1923 în dezbaterea contemporanilor, Bucharest, Humanitas, I27.

Brian, É., Jaisson, M. 2007. The Descent of Human Sex Ratio at Birth. A Dialogue between Mathematics, Biology and Sociology 4, 255.

Bystydzienski, J.M. 2005. Negotiating the New Market: Women, Families, Women's Organizations and the Economic Transition in Poland. Journal of Family and Economic Issues 26, 2, 239265.

Carter, D.A., Simkins, B.J., Simpson, W.G. 2003. Corporate Governance, Board Diversity, and Firm Value. The Financial Review 38, 33-53.

Caselli, G., Vallin, J. 20or. Dynamique de la population: mouvement et structure. In G. Caselli Graziella, Vallin, Jaques et al., Démographie : analyse et synthèse, Vol. I : La dynamique des populations, Paris: INED: 35-79.

Caselli, G., Vallin J. I97I. The Genetics of Human Populations. San Francisco, Freeman, 965.

Ceausescu, N. 1966. Decret No.770/1966, IX.

Chahnazarian, A. I988. Determinants of the sex ratio at birth: review of recent literature. Social Biology 35, 3-4, 214-235.

Chelcea, S. 2007. Metodologia cercetarii sociologice. Metode cantitative si calitative. Editura Economica, Bucharest, 207.

Chimiak, G. 2003. Bulgarian and Polish women in the public sphere. International Feminist Journal of Politics 5, I, 3-27.

Claringbould, I., Knoppers, A. 2007. Finding a 'Normal' Woman: Selection Processes for Board Membership. Sex Roles 56, 495-507.
Cornell, R.W.i987. Labour Power and Chatexis. In Gender and Power: Society, The Person and Sexual Politics. Standford University Press: Io8.

Cromie, W.J. I998. Why women live longer than men. Harvard University Gazette or.

Dawisha, K., Deets, S. 2006. Political Learning in Post-Communist Elections. East European Politics and Societie 20, 69I-728.

David, P.H., Wright, H.N. I971. Abortion Legislation. The Romanian Experience. Studies in Family Planning 2, I0, 205-210.

Dewatripont, M., Jewitt, I., Tirole, J.I999. The Economics of Career Concerns, Part II: Application to Mission and Accountability in Government Agencies. Review of Economic Studies 66, I, I99-2I7.

Directive 73/2002 of the European Parliament and of the Council of 23 September 2002. Official Journal L 269 of 5.I0.2002.

Dumitrache, L. 2004. Starea de sanatate a populatiei Romaniei. Bucharest, Univers Enciclopedic, 99-Ioo.

European Institute for Gender Equality 2006. Roadmap for equality between women and men (2006-20Io. Regulation (EC) No I922/2006 of the European Parliament and of the Council of 20 December 2006 on establishing a [Official Journal L 403 of 30.12.2006]. http://europa.eu/ scadplus/leg/en/cha/cro404.htm.

Falloux, F., Talbot, L.. I992. Crise et opportunité. Environnment et development en Afrique, Paris, Maisonnevre et Larose: 163, 204, 209, 315, 320.

Francoeur, C., Labelle, R., Sinclair-Desgagné, B. 2008. Gender Diversity in Corporate Governance and Top Management. Journal of Business Ethics 8I, 83-95.

Gilbert, R.M. I998. Race, Space and Power: The Survival Strategies of working Poor Women. Annals of American Geographers 88, 4, 595-62I.

Greenberg, R.A., White, C. I967. The sexes of consecutive sibs in human sibships. Human Biology 39, 374-404.

Groza, O., Muntele, 1. 2005. Geografie umană generală. Iasi: Editura Universităţii „A. I. Cuza”.

Harlap, S. I979. Gender of infants conceived on different days of the menstrual cycle. New England Journal of Medicine 300, I445-I448.

Henry, L., Blum, A. I988. Techniques d'analyse en démographie historique. Paris, INED, I80.

Hirschmann, D. I993. Democracy and Gender - A Practical Guide for Application to USAID Programs. Washington DC: USAID Women in Development Office.

Hord, Ch., David, P.H., Donnay, F., Wolf, M. I99I. Reproductive Health in Romania: Reversing The Ceausescu Legacy. Studies in Family Planning 22, 4, 213-240. 
Ianoş, I. 2004. Dinamica urbană, aplicaţii la oraşul şi sistemul urban românesc Bucharest. Editura Tehnica 3I-32, I54-I69.

Jaggar, A.M. 2002. Vulnerable women and neoliberal globalization: debt burdens undermine women's health in the global south. Theoretical Medicine 23, 425-440.

James, W.H. I996. Genetic and non genetic determinants of the human sex ratio at birth. $\mathrm{Hu}$ man Reproduction II, 939-940.

Johnson, R.B., Horga, M., Andronache, L. 1996. Women's Perspectives on Abortion In Romania. Social Science and Medicine 42, 4, 52I-530.

Jurnalul National 2007. Ilustraţiunea Romană - Dreptul de vot al femeilor din Romania, 2I.IV.2007,http://www.jurnalul.ro/index.php? section=rubrici\&article_id=9I427

Kligman G. I992. The politics of reproduction in Ceausescu's Romania: a case study in political culture. East European Politics and Societies 6, 3, 364-4I8.

Lipson, J., Doiron, N. 2006. Environmental Issues and Work: Women with Multiple Chemical Sensitivities. Health Care for Women International 27, 7, 57I-584(I4).

Law no. 342./I98I. Conventia asupra eliminarii tuturor formelor de discriminare fata de femeie, Romania Official Bulletin (Buletinul Oficial al Romaniei), part I, no. 9428 Nov. I98I.

Law no.202/2002. Official Monitor, Part I no. 30I, 8 May 2002.

Marinas, M.C. 2005. The Structural Convergence of the Romanian Economy. Comparative Analyses, p. 28. Applied and Theoretical Economy. www.ectap.ro/articole/I4.pdf.

Moser, O.N.C. I993. Gender Planning and Development: Theory, Practice and Training. London: Routledge, 28.

Murphy, E., Graff, I.J. 2005. Getting Even: Why Women Don't Get Paid Like Men and What to Do About It. Touchstone, New York, I45-I70.

National Institute of Statistics. 2002. Census of population and dwellings. www.insse.ro/cms/ rw/pages/rpl2002.

National Institute of Statistics. 2007. Statistical Yearbook. www.insse.ro/cms/rw/pages/index. ro.do.

Noin, D. 2005. Géographie de la population. Armand Colin, Paris, I52-I55.

OSI. 2007. Country Reports on Human Rights Practices. www.state.gov/g/drl/rls/hrrpt/2007/ I00580.htm.
Oprica, V. 2008. Gender Equality and Conflicting Attitudes Toward Women in Post-Communist Romania. Human Rights Revue 9, 29-40.

Pressat, Roland. 1983. L'analyse démographique. PUF, Paris, 295.

Raghuram, P. 2007. Migrant Women in MaleDominated Sectors of the Labour Market: A Research Agenda. Population, Space and Place I4, 43-57.

Riley, J.C. 20or. Rising the life expectancy: A global History. Cambridge University Press.

Rosenberg, M. 2007. Overview of Life Expectancy. Geography. www.geography.about.com/ od/ populationgeography/a/lifeexpectancy.htm

Romania's Constitution I99I. Official Monitor, Part I, no. 767, from 31/10/2003.

Romania's Parliament 2007 www.parlament.ro; www.cdep.ro/pls/parlam/structura.de?par=A; http://www.cdep.ro/pls/parlam/structura.fp?i $\mathrm{dp}=40 \& \mathrm{cam}=\mathrm{I} \& \mathrm{leg}=2004 \& \mathrm{prn}=0$.

Rutherford, S. 200I. Organizational cultures, women managers and exclusion. Women in Management Review I6, 37I-373.

Sieff, D.F. I990. Explaining biased sex ratios in human populations: a critique of recent studies. Current Anthropology 3I, I, 25-48.

Solano, D., Rafferty, A.M. 2007. Can lessons be learned from history? The origins of the British imperial nurse labour market: A discussion paper. International Journal of Nursing Studies 44, 6, 1055 - 1063.

Surd, V. 2002. Introducere în geografia spaţiului rural. Editura Presa Clujeană, Cluj Napoca.

Tremblay, M. 1997. Transmission intergénérationnelle de la reproduction au Saguenay à la fin du $\mathrm{XIX}^{\mathrm{e}}$ siècle. Cahiers québécois de démographie 26 , I, I29-I45.

United Nations I995. Fourth World Conference on Women. Platform For Action, Beijing. www. un.org/women.

Weinberg, C.R., Baird, D.D., Wilcox, A.J. I995. The sex of the baby may be related to the length of the follicular phase in the conception cycle. Human Reproduction 95, 304-307.

Whitfield, A.G., Bayliss, R., Clarke, C. I987. Deaths in the first 20 years and problems of the sex ratio at birth. Research Unit, Royal College of Physicians 2I, 4, 270-274.

Yamada, T., Yamada, T. I987. Part-Time Work Vs. Full-Time Work of Married Women in Japan. NBER Working Paper Series, Vol. I608, I985 Available at SSRN: http://ssrn.com/abstract $=336338$ 